\title{
Načini zatiranja marmorirane smrdljivke (Halyomorpha halys [Stål, 1855], Hemiptera, Pentatomidae)
}

\author{
Žiga LAZNIK ${ }^{1,2}$, Stanislav TRDAN ${ }^{1}$
}

Received Februay 27, 2021; accepted March 03, 2021. Delo je prispelo 27. februarja 2021, sprejeto 03.03. 2021.

\begin{abstract}
Načini zatiranja marmorirane smrdljivke (Halyomorpha halys [Stål, 1855], Hemiptera, Pentatomidae)

Izvleček: Marmorirana smrdljivka (Halyomorpha halys [Stål, 1855]; [Hemiptera, Pentatomidae]) je predstavnik družine ščitastih stenic. Gre za invazivno, tujerodno in polifagno vrsto, ki izvira iz Vzhodne Azije. Sredi 90-ih je bila vnesena v ZDA ter leta 2004 v Evropo. Danes se pojavlja v večini evropskih držav. $\mathrm{V}$ novih okoljih se hitro prilagaja in uspešno razmnožuje, pri čemer razvije najmanj en popoln rod letno. $\mathrm{Z}$ naraščanjem populacij postaja moteč dejavnik v urbanem okolju ter v zadnjem času eden od najpomembnejših škodljivcev v kmetijski pridelavi. V Sloveniji smo stenico prvič našli leta 2017 v Šempetru pri Gorici. V slabih dveh letih se je razširila po celotni Sloveniji ter začela povzročati škodo $\mathrm{v}$ kmetijski pridelavi. V preglednem članku smo zbrali raziskave tujih in domačih raziskovalcev, vezanih na preučevanje različnih načinov zatiranja marmorirane smrdljivke. V članku so predstavljeni tako kemični načini zatiranja, uporaba insekticidnih mrež, atraktantov in repelentov, privabilnih posevkov kot tudi načini biotičnega varstva $\mathrm{z}$ uporabo plenilcev in parazitoidov.

Ključne besede: Halyomorpha halys; kemično zatiranje; atraktanti; repelenti; privabilni posevki; insekticidne mreže; biotično varstvo rastlin; Slovenija
\end{abstract}

Management methods for marmorated stink bug (Halyomorpha halys [Stål, 1855], Hemiptera, Pentatomidae)

Abstract: The brown marmorated stink bug (Halyomorpha halys (Stål, 1855); [Hemiptera, Pentatomidae]) is an invasive, alien and polyphagous insect species native to East Asia. It was introduced to the United States in the mid-1990s and to Europe in 2004. Today it is present in most European countries. In new environments, it adapts quickly and reproduces successfully, developing at least one complete generation per year. With the growth of populations, it is becoming a disturbing factor in the urban areas and recently one of the most dangerous pests in agricultural production. It was first discovered in Slovenia in 2017 in Šempeter near Gorica. In less than two years, it spread to the entire territory od Slovenia and began to cause damage to agricultural production. In a review paper, we have collected research by foreign and domestic researchers related to the study of different ways of controlling the brown marmorated stink bug. The article presents chemical methods of control, the use of insecticide nets, the use of attractants and repellents, trap crops, as well as methods of biotic protection using predators and parasitoids.

Key words: Halyomorpha halys; chemical control; attractants; repellents; trap crops; insecticidal nets; biological control; Slovenia

1 Univerza v Ljubljani, Biotehniška fakulteta, Oddelek za agronomijo, Jamnikarjeva, Ljubljana, Slovenija

2 Korespondenčni avtor, e-naslov: ziga.laznik@bf.uni-lj.si 


\section{UVOD}

Na področju omejevanja številčnosti marmorirane smrdljivke (Halyomorpha halys) in preprečevanje škode $\mathrm{v}$ kmetijski pridelavi $\mathrm{v}$ tem trenutku nimamo na razpolago prav veliko ukrepov, kot tudi ne učinkovitih rešitev. Opravka imamo z izjemno »robustnim « škodljivcem, ki se ga ne da enostavno obvladovati $z$ insekticidi. Marmorirana smrdljivka je predstavnik družine Pentatomidae. Gre za invazivno, tujerodno in polifagno vrsto, ki izvira iz Vzhodne Azije (Panizzi in sod., 2000; Lee in sod., 2013a). Vrsta je bila sredi 90 -ih vnesena v ZDA (Hoebeke in Carter, 2003; Morrison in sod., 2017) ter leta 2004 v Evropo (Leskey in sod., 2012a; Rice in sod., 2014). Danes se pojavlja v večini evropskih držav. V novih okoljih se hitro prilagaja in uspešno razmnožuje, pri čemer razvije najmanj en popoln rod letno (Leskey in sod., 2012a). Z naraščanjem populacij postaja moteč dejavnik v urbanem okolju ter v zadnjem času eden najbolj nevarnih škodljivcev v kmetijski pridelavi (Inkley, 2012). V Sloveniji smo jo prvič odkrili leta 2017, in sicer v Šempetru pri Gorici. V slabih dveh letih se je razširila na območju celotne Slovenije ter začela povzročati škodo $\mathrm{v}$ kmetijski pridelavi (Rot in sod., 2018).

Vrsta je polifag. Prehranjuje se s preko 150 različnimi rastlinskimi vrstami iz številnih družin, med katerimi prevladujejo metuljnice in rožnice (Morrison in sod., 2017). Med sadnimi vrstami so njeni najpomembnejši gostitelji hruška, jablana, breskev, leska, kaki in aktinidija (Leskey in sod., 2012a). Škodo povzroča tudi na vinski trti, na plodovkah (paradižnik, paprika, jajčevec, kumare) in stročnicah (fižol). V pridelavi poljščin so najbolj ogroženi posevki soje ter koruze. Prehranjuje se tudi na številnih okrasnih rastlinah in grmovnicah ter prosto rastočih drevesnih vrstah, kot so: veliki jesen (Fraxinus excelsior L.), visoki pajesen (Ailanthus altissima [Mill.] Swingle), pavlovnija (Paulownia tomentosa [Thunb.] Steud.), jerebika (Sorbus aucuparia L.), lovorikovec (Prunus laurocerasus L.), oslez (Hibiscus spp.), vrtnica (Rosa sp.), navadna bodika (Ilex aquifolium L.) in številnih druge (Nielsen in Hamilton, 2009; Leskey in sod., 2012a; Morrison in sod., 2017).

V ZDA, kjer je marmorirana smrdljivka zastopana najdlje, je škoda, ki jo je povzročila $v$ kmetijski pridelavi ocenjena na nekaj milijard dolarjev. V letu 2010 je pridelovalcem jabolk na območju Srednjega Atlantika povzročila škodo v višini 34 mio. \$, sočasno so pridelovalci breskev beležili 50 \% izgube pridelka (Leskey in sod., 2012a; Morrison in sod., 2017). V Evropi je do sedaj povzročila največ škode $v$ Italiji, $v$ pridelavi hrušk in jabolk (Cesari in sod., 2015). V deželi Emiglia Romagna, $v$ provinci Modena je bilo v letu 2015 zaradi močnega napada marmorirane smrdljivke poškodovanih od
30 do 50 \% hrušk (Cesari in sod., 2015). Z Madžarske poročajo o veliki škodi $\mathrm{v}$ pridelavi fižola in paprike, $\mathrm{v}$ Gruziji in Abhaziji je zaradi marmorirane smrdljivke ogrožena pridelava lešnikov (Morrison in sod., 2017). Poleg škode v kmetijski pridelavi je po vsej Evropi postala moteč dejavnik v urbanem okolju. Zaradi specifičnega načina prezimovanja, $v$ jesenskem času stenice množično priletajo $\mathrm{v}$ bližino človeških bivališč. $\mathrm{V}$ iskanju skupnega zimskega zavetja izločajo agregacijske feromone ter se množično zbirajo na fasadah hiš, kar povzroča prave invazije žuželk (Inkley, 2012).

V nasadih se škodljivec pojavlja od cvetenja do zorenja plodov gostiteljskih rastlin. Obdobje, v katerem povzroča škodo, je izjemno dolgo. Kemično zatiranje marmorirane smrdljivke, vezano na pragove škodljivosti, zahteva veliko število škropljenj, kar negativno vpliva na agroekosistem, obremenjuje okolje in je v popolnem nasprotju $\mathrm{z}$ vzpostavljenim sistemom integriranega varstva (Morrison in sod., 2017). Dolgoročno gre pričakovati, da se bodo domorodni koristi organizmi sčasoma prilagodili na novega tujerodnega škodljivca ter ga začeli omejevati na dopustno raven. Izkušnje iz tujine kažejo, da je obvladovanje marmorirane smrdljivke izjemno zahteven proces, ki mora združevati številne ukrepe varstva rastlin (Morrison in sod., 2017). Temeljiti morajo na zanesljivih metodah spremljanja populacije škodljivih organizmov, predvidevanju nastanka škode ter pravočasni napovedi in izvedbi ukrepov.

\section{SPREMLJANJE POPULACIJSKE DINAMI- KE MARMORIRANE SMRDLJIVKE}

Za spremljanje populacijske dinamike različnih vrst domorodnih stenic se $\mathrm{v}$ praksi navadno uporabljajo različne detekcijske metode, kot so uporaba metuljnice, otresanje rastlin, feromonske vabe in UV oz. črne svetilke (svetilke, ki oddajajo vijolično in modro kratkovalovno sevanje) (Krupke in sod., 2001; Leskey in Hogmire, 2005; Kamminga in sod., 2009; Borges in sod., 2011). Za spremljanje populacijske dinamike marmorirane smrdljivke so se $\mathrm{v}$ praksi sprva uporabljale piramidalne pasti $\mathrm{z}$ uporabo agregacijskega feromona (metil [2E, 4E, 6Z]-dekatrienoat) stenice Plautia stali Scott (Nielsen in sod., 2011; Laskey in sod., 2012b; Joseph in sod., 2013). Raziskovalci so ugotovili, da omenjeni feromon deluje na marmorirano smrdljivko kot kairomon (Aldrich in sod., 2007; Khrimian in sod., 2008). Nadaljnje raziskave so pokazale, da feromon (metil [2E, 4E, 6Z]-dekatrienoat) ne vpliva na gibanje marmorirane smrdljivke spomladi in zgodaj poleti in je zato uporaben le pri pozno poletnem in jesenskem lo- 
vljenju stenic (Leskey in sod., 2012b). Khrimian in sod. (2014) so ugotovili, da dvokomponentno privabilo, ki ga sestavljata agregacijski feromon (murgantiol) ter sinergistično sredstvo metil-dekatrienoat (MDT) vplivata tako na ličinke kot tudi na odrasle osebke marmorirane smrdljivke skozi celotno rastno dobo. Njihovo raziskavo so potrdili tudi rezultati nekaterih sorodnih raziskav (Weber in sod., 2014; Leskey in sod., 2015; Morrison in sod., 2017; Rice in sod., 2018), v katerih so se predvsem ukvarjali $\mathrm{z}$ ugotavljanjem razmerij različnih vrst agregacijskih feromonov in njihovim učinkom na lovljenje populacij marmorirane smrdljivke. Poznavanje agregacijskih feromonov marmorirane smrdljivke predstavlja podlago za strategijo "privabi in ubij (angl. "attract and kill"), kjer s feromoni privabimo na izbrano rastlinsko vrsto škodljivca in ga nato $\mathrm{z}$ uporabo drugih tehnik (kemično, biotično varstvo, mehansko $\mathrm{z}$ uporabo insekticidnih sesalcev) zatremo (Morrison in sod, 2016). Iz ZDA poročajo tudi o spremljanju populacijske dinamike $\mathrm{z}$ uporabo svetlobnih vab (bela, črna in modra dolgovalovna svetloba), vendar so potrdili uspešnost uporabe zgolj pri lovljenju odraslih osebkov (Nielsen in sod., 2013).

\section{UPORABA ETERIČNIH OLJ}

Rastlinska eterična olja predstavljajo alternativni način zatiranja škodljivih žuželk v kmetijstvu (Isman, 2006). Eterična olja so vir aktivnih, močnih presnovkov, ki lahko vplivajo na bionomijo, vedenje in fiziologijo žuželk. Poleg tega imajo kratko obstojnost v okolju in majhno toksičnost za sesalce in so zaradi široke uporabe kot dišave in arome navadno na voljo v velikih količinah po razumnih cenah (Isman, 2006). Dosedanje raziskave so pokazale, da eterična olja navadno delujejo kot repelenti za različne skupine žuželk (Moore in sod., 2007; Zhang in sod., 2013).

Zhang in sod. (2014) so preučevali vpliv različnih eteričnih olj (nageljnove žbice, limonina trava, poprova meta) in ugotovili, da prav vsa vplivajo odvračalno na ličinke kot tudi odrasle osebke marmorirane smrdljivke. V nadaljevanju so kitajski raziskovalci naredili kemično analizo eteričnih olj in določili več kot 20 aktivnih snovi. Nekatere med njimi (evgenol, karvon, menton, pulegon, metil salicilat, trans/cis-citral, metil benzoat in $\beta$-kariofilen) so $\mathrm{v}$ primerjavi $\mathrm{z}$ atraktanti (MDT) zmanjšali ulov marmorirane smrdljivke $\mathrm{v}$ lovilnih posodah za 72 do $99 \%$. Raziskovalci zaključujejo, da lahko kombinacija repelentov in atraktantov, razporejenih na kmetijskih in urbanih zemljiščih, predstavlja t.i. »odvrni in privabi (angl. "push and pull”) strategijo zatiranja marmorirane smrdljivke.

\section{KEMIČNO ZATIRANJE MARMORIRANE SMRDLJIVKE}

Marmorirana smrdljivka postaja vedno večji problem v kmetijstvu, zato raziskovalci širom sveta iščejo učinkovite ukrepe z željo po omejitvi njene številčnosti in posledično zmanjšanju gospodarske škode na gojenih rastlinah. Leskey in sod. (2012c) poročajo o neučinkovitosti insekticidov, ki se navadno uporabljajo za zatiranje nekaterih drugih vrst stenic v ZDA. Lee in sod. (2013a) so pripravili pregled literature, vezane na učinkovitost različnih vrst insekticidov, ki jih v Aziji uporabljajo za zatiranje marmorirane smrdljivke. Ugotovljeno je bilo, da so nekateri insekticidi iz skupine kloriranih ogljikovodikov, organskih fosforjevih estrov, karbamatov, piretroidov in neonikotinoidov pokazali zelo veliko učinkovitost pri kontaktnem zatiranju marmorirane smrdljivke (Bae in sod., 2008). Žal večina teh pripravkov ni registriranih v ZDA in Evropi za zatiranje škodljivca oz. so bile nekatere aktivne snovi celo zakonsko umaknjene iz trgovskih polic. Zato raziskovalci iščejo ustrezne novejše rešitve na področju kemičnega zatiranja marmorirane smrdljivke.

$\mathrm{V}$ raziskavah, ki so jih opravili $\mathrm{v}$ ZDA, so tako $\mathrm{v}$ obdobju med leti 2008 in 2017 različne skupine raziskovalcev opravile serije laboratorijskih preizkušanj učinkovitosti različnih vrst insekticidov pri zatiranju marmorirane smrdljivke (Nielsen in sod., 2008; Kuhar in sod., 2012; Leskey in sod., 2012c; Lee in sod., 2013b; Kuhar in Kamminga, 2017). Nielsen in sod. (2008) so potrdili veliko toksičnost piretroidov (bifentrin, beta-ciflutrin, lambda cihalotrin, ciflutrin in fenpropatrin) pri zatiranju marmorirane smrdljivke. Zadovoljivo učinkovitost so pokazali tudi nekateri neonikotinoidi (dinetofuran in tiametoksam). Nielsen in sod. (2008) so tudi potrdili, da je zatiranje ličink marmorirane smrdljivke bolj učinkovito kot zatiranje odraslih osebkov. $\mathrm{V}$ sorodni raziskavi so Leskey in sod. (2012c) potrdili učinkovitost piretroidov (bifentrin, fenpropatrin, permetrin), organskih fosforjevih estrov (dimetoat, malation, metidation, klorpirifos, acefat), karbamatov (metomil) in kloriranih ogljikovodikov (endosulfan). Krawczyk in sod. (2011) so potrdili veliko učinkovitost aktivnih snovi bifentrin, metomil, endosulfan in večine neonikotinoidov (razen a.s. tiakloprid) pri zatiranju vseh razvojnih stadijev marmorirane smrdljivke. Kuhar in sod. (2012) so potrdili učinkovitost acefata, oksamila, zeta-cipermetrina, fenpropatrina, lambda-cihalotrina in acetamiprida pri zatiranju ličink marmorirane smrdljivke. Njihovi rezultati so potrdili tezo Nielsen in sod. (2008), da so ličinke bolj občutljive na delovanje insekticidov kot odrasli osebki marmorirane smrdljivke. Lee in sod. (2013b) poročajo o $100 \%$ učinkovitosti 
Preglednica 1: Učinkovitost insketicidov pri zatiranju marmorirane smrdljivke (Halyomorpha halys) v laboratorijskih razmerah. Table 1: Performance of insecticides against the brown marmorated stink bug (Halyomorpha halys) in laboratory bioassays.

\begin{tabular}{|c|c|c|c|}
\hline Insekticid & Učinkovitost & Insekticid & Učinkovitost \\
\hline Organski fosforjevi estri & & Neonikotinoidi & \\
\hline Dimetoat & 4 & Dinotefuran & 3,3 \\
\hline Malation & 4 & Klotianidin & 2,8 \\
\hline Metidation & 4 & Tiametoksam & 2,8 \\
\hline Klorpirifos & 3 & Acetamiprid & 2,3 \\
\hline Metal paration & 3 & Imidakloprid & 1,5 \\
\hline Acefat & 2,5 & Tiakloprid & 1,5 \\
\hline Formetanat & 2 & & \\
\hline Azinfos-metil & 1 & Klorirani ogljikovodiki & \\
\hline Diazinon & 1 & Endosulfan & 4 \\
\hline \multirow[t]{2}{*}{ Fosmet } & 1 & & \\
\hline & & Druge skupine insekticidov & \\
\hline Karbamati & & Spinetoram & 1 \\
\hline Metomil & 3,3 & Abamektin & 1 \\
\hline Oksamil & 2 & Piriproksifen & 1 \\
\hline \multirow[t]{2}{*}{ Karbaril } & 1,5 & Priflukuinazon & 1 \\
\hline & & Novaluron & 1 \\
\hline Piretroidi & & Tlfenpirad & 1 \\
\hline Etofenproks & 4 & Indoksakarb & 1 \\
\hline Bifentrin & 3,8 & Spirotetramat & 1 \\
\hline Permetrin & 3 & Klorantranilprol & 1 \\
\hline Fenpropatrin & 2,8 & Ciantranilprol & 1 \\
\hline Lambda-cihalotrin (LC) & 2,8 & Flonikamid & 1 \\
\hline Ciflutrin & 2,7 & & \\
\hline Beta-ciflutrin (BC) & 2,5 & Kombinirana uporaba & \\
\hline Cipermetrin & 2,5 & Tiametoksam + klorantranilprol & 4 \\
\hline Gama-cihalotrin & 2 & Beta ciflutrin + imidakloprid & 3,7 \\
\hline Zeta-cipermetrin (ZC) & 2 & $\mathrm{LC}+$ tiametoksam & 3,7 \\
\hline \multirow[t]{3}{*}{ Esfenvalerat } & 1 & Bifentrin + imidacloprid & 3 \\
\hline & & $\mathrm{ZC}+$ bifentrin & 3 \\
\hline & & LC + klorantranilprol & 1 \\
\hline
\end{tabular}

Legenda: učinkovitost pripravka 1 (<50\%), 2 (50-69 \%), 3 (70-89 \%), 4 (90-100 \%) (Nielsen in sod., 2008; Krawczyk in sod., 2011; Leskey in sod., 2012c; Kuhar in sod., 2012; Lee in sod., 2013b; Kuhar in Kamminga, 2017).

aktivnih snovi metomil, acefat, klorpirifos, dimetoat, malation, metidation, bifentrin, fenpropatrin, permetrin, dinotefuran in endosulfan pri zatiranju odraslih osebkov marmorirane smrdljivke. Pregled učinkovitosti posameznih aktivnih snovi pri zatiranju marmorirane smrdljivke v laboratorijskih razmerah je predstavljen $\mathrm{v}$ preglednici 1.

Pridobljeni laboratorijski rezultati so skupine raziskovalcev vodili tudi na preizkušanje učinkovitosti in- sekticidov pri zatiranju marmorirane smrdljivke na prostem (Bergmann in Raupp, 2014; Leskey in sod., 2014; Monneyham in sod., 2016; Kuhar in Kamminga, 2017). Učinkovitost insekticidov $\mathrm{v}$ laboratorijskih preizkusih je dostikrat večja od tiste, ki jo dosežemo v poskusih na prostem zaradi številnih omejujočih dejavnikov, ki jih $\mathrm{v}$ laboratoriju lahko reguliramo. Ker se marmorirana smrdljivka lahko premika na daljše razdalje (Lee in Leskey, 2015) kot tudi med različnimi gostiteljskimi rastlinami 
Preglednica 2: Insekticidi, ki so pokazali visoko učinkovitost pri zatiranju marmorirane smrdljivke (Halyomorpha halys) na prostem.

Table 2: Insecticides that provided a significant reduction of the brown marmorated stink bug (Halyomorpha halys) in field efficacy experiments.

\begin{tabular}{|c|c|c|}
\hline \multicolumn{3}{|c|}{ Skupina insekticidov } \\
\hline Organofosfati & Neonikotinoidi & Kombinirana uporaba \\
\hline Acefat & Dinotefuran & Tiametoksam + klorantranilprol \\
\hline \multirow[t]{2}{*}{ Fosmet } & Klotianidin & $\mathrm{BC}+$ imidakloprid \\
\hline & Tiametoksam & $\mathrm{LC}+$ tiametoksam \\
\hline Karbamati & & Bifentrin + imidacloprid \\
\hline Metomil & Klorirani ogljikovodiki & $\mathrm{ZC}+$ bifentrin \\
\hline \multirow[t]{2}{*}{ Oksamil } & Endosulfan & LC + klorantranilprol \\
\hline & & $\mathrm{BC}+$ spinetoram \\
\hline Piretroidi & Druge skupine insekticidov & Bifentrin + abamectin \\
\hline Etofenproks & Flupiridafuron & Binfetrin + klorantranilprol \\
\hline Bifentrin & Diflubenzuron & Metomil + fosmet \\
\hline Permetrin & Indoksakarb & Metomil + ZC \\
\hline Fenpropatrin & Klorantranilprol & \\
\hline Lambda-cihalotrin (LC) & Ciklaniprol & \\
\hline Beta-ciflutrin (BC) & Flonikamid & \\
\hline \multicolumn{3}{|l|}{ Gama-cihalotrin } \\
\hline \multicolumn{3}{|l|}{ Zeta-cipermetrin (ZC) } \\
\hline Esfenvalerat & & \\
\hline
\end{tabular}

(Krawczyk in sod., 2011; Kuhar in sod., 2012; Herbert in sod., 2013; Nielsen in Rucker, 2013; Frank, 2014; Walgenbach in Schoof, 2015; Morrison in sod., 2016; Kuhar in Kamminga, 2017).

(Zobel in sod., 2016), je ključnega pomena, da pride $\mathrm{v}$ stik $\mathrm{z}$ letalno dozo aktivne snovi na tretirani rastlini (Morrison in sod., 2016). Le tako je možno doseči zadovoljivo raven učinkovitosti izbranih insekticidov pri zatiranju marmorirane smrdljivke. Leskey in sod. (2014) so ugotovili, da je sveži nanos insekticida na rastlino znatno bolj letalen za marmorirano smrdljivko kot nekaj dni star insekticidni ostanek na rastlini. Omenjeni raziskovalci so to ugotovitev potrdili na primeru aktivnih snovi fenpropatrin ter dinotefuran. Obe aktivni snovi sta se izkazali kot zelo učinkoviti, če je marmorirana smrdljivka prišla v stik z aktivno snovjo takoj, ko je bila le-ta nanesena. Ob poznejšem stiku (po 24h) z aktivno snovjo je bil učinek le-te zanemarljiv. Leskey in sod. (2014) so ugotovili, da insekticidni ostanki na rastlini delujejo na marmorirano smrdljivko odvračalno (vplivajo na zmanjšano hranjenje), ne povzročijo pa njene smrtnosti. Bargmann in Raupp (2014) sta v sorodni raziskavi potrdila pomen takojšnjega stika marmorirane smrdljivke $\mathrm{z}$ insekticidom na primeru aktivnih snovi karbaril, acetamiprid in permetrin. Ostanki aktivnih snovi permetrin in karbaril so v njuni raziskavi vplivali na več kot $80 \%$ smrtnost ličink marmorirane smrdljivke $48 \mathrm{~h}$ po nanosu, medtem ko aktivna snov acetamiprid ni imela učinka na smrtnost le-teh. Mooneyham in sod. (2016) so preučevali učinek devetih registriranih insekticidov, ki se uporabljajo za zatiranje škodljivcev na stavbah. Ugotovili so, da aktivne snovi lambda-cihalotrin (LC), LC + tiametoksam, beta-ciflutrin (BC), BC + imidacloprid učinkujejo (več kot $80 \%$ smrtnost odraslih osebkov marmorirane smrdljivke) tudi po desetih dneh po nanosu na okenske okvirje. Skupine različnih raziskovalcev so $\mathrm{v}$ obdobju med leti 2011 do danes izvedle številne raziskave vezane na preizkušanje učinkovitosti insekticidov pri zatiranju marmorirane smrdljivke na prostem (Krawczyk in sod., 2011; Kuhar in sod., 2012; Herbert in sod., 2013; Nielsen in Rucker, 2013; Frank, 2014; Walgenbach in Schoof, 2015; Morrison in sod., 2016; Kuhar in Kamminga, 2017). Na splošno so se številni insekticidi, ki so bili učinkoviti v laboratorijskih preizkusih, dobro izkazali tudi na prostem. Aktivne snovi, ki so bile najučinkovitejše, so bile iz skupine piretroidov (beta-ciflutrin, bifentrin, permetrin, fenpropatrin, lambda-cihalotrin, zeta-cipermetrin), neonikotinoidov (dinotefuran, klotianidin in tiametoksam), karbamatov (metomil) in kloriranih ogljikovodikov (endosulfan) (Preglednica 2). 


\section{UPORABA INSEKTICIDNIH MREŽ}

Uporaba mrež za zaščito ljudi pred škodljivimi žuželkami je dobro znana in razširjena praksa, katerih uporaba sega v konec 17. stoletja (Da San Gallo, 1679). V kmetijstvu se zaščitne mreže $\mathrm{v}$ zadnjem času uporabljajo tako $\mathrm{v}$ rastlinjakih kot tudi na prostem $\mathrm{z}$ namenom, da zaščitimo rastline pred škodljivimi organizmi (Sauphanor in sod., 2012). Novost v pristopu so t.i. insekticidne mreže, kjer je na mrežo nanesen izbrani insekticid, ki poveča učinkovitost zatiranja škodljivca oz. omejevanja poškodb in posledične škode na gojenih rastlinah (Hill in sod., 2007).

Zaenkrat je najbolj učinkovit način preprečevanja škode, ki jo povzroča marmorirana smrdljivka, ravno uporaba insekticidnih mrež (Kuhar in sod., 2017; Sabbatini Peverieri in sod., 2018). V pridelavi sadja se za ta namen uporabljajo protitočne mreže, nadgrajene s stranskimi mrežami, ki popolnoma preprečijo dostop stenicam do rastlin. $\mathrm{V}$ določenih primerih se na mreže lahko nanese tudi insekticid (Kuhar in sod., 2017). Popolno zamreženje nasadov je potrebno izvesti takoj po cvetenju sadnega drevja (Leskey in Nielsen, 2018). V raziskavi, ki so jo opravili v Italiji (Sabbatini Peverieri in sod., 2018), raziskovalci poročajo o veliki učinkovitosti insekticidne mreže, ki je bila tretirana $z$ a.s. alfa-cipermetrinom, pri zatiranju oz. omejevanju škode, ki jo povzroči marmorirana smrdljivka. Potrdili so več kot $70 \%$ smrtnost odraslih osebkov marmorirane smrdljivke, ki so prišli v stik z insekticidno mrežo. Poskus je bil sicer opravljen v laboratorijskih razmerah. Kuhar in sod. (2017) poročajo o $80 \%$ smrtnosti odraslih osebkov marmorirane smrdljivke, ki so prišli v stik $\mathrm{z}$ insekticidno mrežo, ki je bila tretirana $\mathrm{z}$ a.s. deltametrin. $\mathrm{V}$ poskusu na prostem, so Sabbatini Peverieri in sod. (2018) v nasadu breskev preučevali insekticidno mrežo prepojeno $\mathrm{z}$ alfa-cipermetrinom in deltametrinom. Mrežo so dodatno prepojili tudi $\mathrm{z}$ atraktantom (murgantiol $+\mathrm{MDT}$ ). Raziskava je pokazala veliko umrljivost vseh razvojnih stadijev marmorirane smrdljivke in posledično občutno zmanjšanje škode na rastlinah. Gre za zgled uporabe strategije "privabi in ubij«, ko z atraktantom privabimo škodljivca, ki nato pride v stik z mrežo, ki je prepojena z insekticidom. Prav tako so italijanski raziskovalci preučevali tudi vpliv zaščitnih mrež brez dodatka insekticida na pojav škode, ki jo naredi marmorirana smrdljivka (Candian in sod., 2018). Rezultati raziskave so pokazali $45 \%$ zmanjšanje škode v breskovih nasadih $\mathrm{v}$ primerjavi z netretiranimi nasadi, ter za $20 \%$ zmanjšanje škode v primerjavi z nasadi, ki so bili tretirani $\mathrm{z}$ insekticidom deltametrin (Candian in sod., 2018). V nobeni od omenjenih raziskav raziskovalci niso izpostavili vpliva insekticidnih mrež na neciljne organizme kot tudi ne na koristne vrste žuželk.

\section{METODA PRIVABILNIH POSEVKOV}

Metoda privabilnih posevkov je pogosto uporabljena v primerih, ko za zatiranje škodljivega organizma ni registriranega fitofarmacevtskega sredstva, ko je pripravek predrag oziroma tedaj, ko glavni posevek ni odporen na napad ali okužbo škodljivih organizmov. Pri metodi privabilnih posevkov izkoriščamo lastnosti za škodljivce dovzetnih rastlin (Trdan in sod., 2005; Cook in sod., 2006). Privabilne posevke posadimo oziroma posejemo med rastline glavnega posevka ali v njegovo bližino, z namenom, da bi na dovzetne rastline privabili škodljivce in obenem zmanjšali njihovo številčnost na glavnem posevku (Cook in sod., 2006).

Marmorirana smrdljivka je polifag, saj se hrani z različnimi rastlinskimi vrstami. Soergel in sod. (2015) so preučevali vpliv privabilnih posevkov pri pridelavi paprike. Ugotovili so, da je bil ulov marmorirane smrdljivke na sončnicah (Helianthus annuus L.) v primerjavi s papriko občutno večji. V sklopu raziskave sicer niso ugotovili zmanjšanja poškodb na papriki, kar avtorji pripisujejo predvsem dejstvu, da marmorirane smrdljivke niso zatirali na privabilnih posevkih. Znano je, da je marmorirana smrdljivka zelo mobilna vrsta (Lee in Leskey, 2015), zato predvidevajo, da so se osebki, ki so se $\mathrm{v}$ večjem številu pojavili na sončnicah pozneje vrnili na papriko in na plodovih povzročili gospodarsko škodo. Do podobnih rezultatov so prišli tudi Mathews in sod. (2017), ki so preučevali vpliv mešanih privabilnih posevkov (sončnica in navadni sirek) na zmanjšanje škode, ki jo povzroči marmorirana smrdljivka na papriki. Ulov marmorirane smrdljivke je bil na privabilnih posevkih za $4 \mathrm{x}$ večji kot na glavni rastlini, vendar do zmanjšanja poškodb na plodovih ni prišlo. V sorodni raziskavi so Nielsen in sod. (2016) preučevali različne rastlinske vrste, kot potencialne privabilne posevke. Poleg sončnice so v raziskavo vključili tudi navadni sirek (Sorghum bicolor L.), biserno proso (Pennisetum glaucum [L.]), jedilni oslez (Abelmoschus esculentus Moench) in njivski grah (Pisum sativum var. arvense [L.]). Ulov marmorirane smrdljivke je bil na navadnem sirku za več kot 4 $\mathrm{x}$ večji $\mathrm{v}$ primerjavi $\mathrm{z}$ ostalimi preučevanimi rastlinami. $\mathrm{V}$ nadaljevanju so preizkusili različne metode zatiranja škodljivca na privabilnih posevkih - kemično (azadirahtin), uporaba sesalcev za mehansko odstranjevanje žuželk z rastlin in ožiganje rastlin. Ožiganje rastlin se je izkazalo kot najbolj učinkovito (Nielsen in sod., 2016). Iz dosedanjih rezultatov raziskav je razvidno, da samostojna uporaba metode privabilnih posevkov ni zadostno učinkovit ukrep pri zmanjšanju škode, ki jo povzroči marmorirana smrdljivka na glavni rastlini, temveč je potrebno metodo kombinirati $\mathrm{z}$ uporabo drugih varstvenih ukrepov. 


\section{BIOTIČNO VARSTVO}

Biotično zatiranje marmorirane smrdljivke trenutno temelji predvsem na ugotavljanju ustreznih agensov, ki bi se v prihodnje lahko uporabljali v programih biotičnega varstva rastlin. Parazitske osice iz reda kožekrilcev (Hymenoptera), so znane kot najbolj učinkovit naravni sovražnik marmorirane smrdljivke. Svoja jajčeca odla-

Preglednica 3: Naravni sovražniki marmorirane smrdljivke (Halyomorpha halys).

Table 3: Natural enemies of the brown marmorated stink bug (Halyomorpha halys).

\begin{tabular}{|c|c|c|}
\hline Vrsta naravnega sovražnika & Tip & Razvojni stadij marmorirane smrdljivke \\
\hline Anastatus & parazitoid & jajčeca \\
\hline Anastatus bifastiatus & parazitoid & jajčeca \\
\hline Anastatus mirabilis & parazitoid & jajčeca \\
\hline Anastatus pearsalli & parazitoid & jajčeca \\
\hline Anastatus reduvii & parazitoid & jajčeca \\
\hline Arilus cristatus & plenilec & ličinke, imago \\
\hline Arma chinensis & plenilec & \\
\hline Astata bicolor & plenilec & ličinke \\
\hline Astata unicolor & plenilec & ličinke, imago \\
\hline Astochia virgatipes & plenilec & \\
\hline Bicyrtes quadrifasciatus & plenilec & ličinke \\
\hline Bogosia & parazitoid & imago \\
\hline Geocoris & plenilec & jajčeca, ličinke \\
\hline Gryon japonicum & parazitoid & jajčeca \\
\hline Gryon obesum & parazitoid & jajčeca \\
\hline Harmonia axyridis & plenilec & jajčeca \\
\hline Isyndus obscurus & plenilec & \\
\hline Misumenops tricuspidatus & plenilec & \\
\hline Ooencytrus & parazitoid & jajčeca \\
\hline Ophiocordyceps nutans & patogen & \\
\hline Orius & plenilec & jajčeca \\
\hline Telenomus chlorupus & parazitoid & jajčeca \\
\hline Telenomus podi & parazitoid & jajčeca \\
\hline Trichopoda pennipes & parazitoid & ličinke, imago \\
\hline Trissolcus brochymenae & parazitoid & jajčeca \\
\hline Trissolcus cultratus & parazitoid & jajčeca \\
\hline Trissolcus edessae & parazitoid & jajčeca \\
\hline Trissolcus euschisti & parazitoid & jajčeca \\
\hline Trissolcus flavipes & parazitoid & jajčeca \\
\hline Trissolcus itoi & parazitoid & jajčeca \\
\hline Trissolcus japonicus & parazitoid & jajčeca \\
\hline Trissolcus mitsukurii & parazitoid & jajčeca \\
\hline Trissolcus scutellaris & parazitoid & jajčeca \\
\hline Trissolcus semistriatus & parazitoid & jajčeca \\
\hline Trissolcus thyantae & parazitoid & jajčeca \\
\hline Trissolcus utahensis & parazitoid & jajčeca \\
\hline
\end{tabular}

(Arakawa in Nakamura, 2003; Li in Liu, 2004; Yang, 2009; Haye in sod., 2015; Abram in sod., 2017, Dieckhoff in sod., 2017; Costi in sod., 2019). 
gajo $\mathrm{v}$ jajčeca gostitelja in povzročajo njihov propad. V Aziji, v izvornem okolju marmorirane smrdljivke, je razširjena vrsta Trissolcus japonicus (Ashmead, 1904), ki je znana kot njen najbolj učinkovit parazitoid (Yang, 2009). V Severni Ameriki in Evropi je bilo ugotovljenih več različnih rodov jajčnih parazitoidov, potencialnih naravnih sovražnikov $H$. halys, ki pripadajo trem družinam: Scelionidae (Telenomus, Trissolcus, Gryon spp.), Eupelmidae (Anastatus spp.) in Encyrtidae (Ooencyrtus spp.). Osice iz rodov Telenomus in Trissolcus (Scelionidae) so znane kot specializirani jajčni parazitoidi ščitastih stenic (Hemiptera: Pentatomidae), medtem ko so parazitoidi iz rodov Anastatus in Ooencyrtus bolj generalisti in napadajo žuželke iz različnih družin (Abram in sod., 2017, Dieckhoff in sod., 2017). Raziskave, opravljene v Švici, so potrdile zastopanost vrst Anastatus bifasciatus (Geoffroy), Trissolcus cultratus (Mayr), Trissolcus semistriatus (Nees), Trissolcus scutellaris (Thomson), Trissolcus cultratus Mayr in Telenomus chloropus (Thomson) (Haye in sod., 2015). Rezultati triletnega spremljanja zastopanosti domorodnih jajčnih parazitoidov $\mathrm{v}$ Emigli Romagni $\mathrm{v}$ Italiji, so potrdili zastopanost vrste A. bifasciatus. Stopnja parazitizma je znašala od 1 do $3 \%$ (Costi in sod., 2019). $\mathrm{V}$ preglednici 3 navajamo naravne sovražnike marmorirane smrdljivke. V Evropi je v teku več raziskav $\mathrm{z}$ namenom preizkušanja učinkovitosti domorodnih naravnih sovražnikov marmorirane smrdljivke. Kot obetavna sta se pokazala jajčna parazitoida Ooencyrtus telenomicida (Vassiliev 1904) [Hymenoptera] in Anastatus bifasciatus [Hymenoptera] (Costi in sod., 2019). Prvi je učinkovitost izkazal zlasti v laboratorijskih poskusih, medtem ko je v poljskih poskusih pokazal omejeno delovanje. Nadaljujejo se tudi raziskave vrste $A$. bifasciatus, ki je v laboratorijskih poskusih pokazala manjšo učinkovitost pri parazitiranju $H$. halys v primerjavi z vrsto $O$. telenomicida, vendar pa je zaradi bioloških značilnosti najresnejši kandidat za klasično biotično varstvo marmorirane smrdljivke (Dieckhoff in sod., 2017). A. bifasciatus se razvija in razmnožuje v temperaturnem območju $15-32{ }^{\circ} \mathrm{C}$, letno razvije do 3 rodove v obdobju od junija do oktobra, kar se ujema s periodo ovipozicije pri marmorirani smrdljivki. Samice se hranijo na jajčecih gostitelja, hkrati vanje odlagajo lastna jajčeca, kar povzroči smrt gostitelja. Na podlagi obetavnih rezultatov začetnih raziskav, nameravajo raziskovalci Univerze iz Modene in Mednarodnega centra za kmetijstvo in bioznanosti (CABI), ki deluje v Švici, razviti protokole za masovno gojenje parazitoida $A$. bifasciatus, ki bodo podlaga za morebitno komercialno rabo (Costi in sod., 2019).

Eno od možnih alternativ predstavlja tudi uporaba entomopatogenih gliv in entomopatogenih ogorčic pri zatiranju marmorirane smrdljivke. Gouli in sod. (2012) so $\mathrm{v}$ laboratorijskih razmerah preučevali učinkovitost različnih sevov entomopatogene glive Beauveria bassiana (Bals.-Criv.) Vuill. ter Metarhizium anisopliae (Metchnikoff) Sorokin pri zatiranju odraslih osebkov marmorirane smrdljivke. Vsi sevi $B$. bassiana so se v poskusu izkazali za bolj učinkovite od glive $M$. anisopliae. S sevom B. bassiana GHA (Botanigard ${ }^{\circledR}$, Mycotech Europe Limited; Metrob d.o.o.) so dosegli med 85 in $100 \%$ smrtnost odraslih osebkov marmorirane smrdljivke. Burjanadze in sod. (2020) so v laboratorijskih razmerah preučevali učinkovitost različnih vrst entomopatogenih ogorčic (Heterorhabditis bacteriophora Poinar, Steinernema borjomiense n.sp. in Steinernema apuliae sp.n.). Z ogorčico $H$. bacteriophora so dosegli okoli $80 \%$ smrtnost odraslih osebkov marmorirane smrdljivke.

\section{ZAKLJUČEK}

Na področju omejevanja številčnosti marmorirane smrdljivke in preprečevanje škode v kmetijski pridelavi v tem trenutku nimamo na razpolago prav veliko ukrepov, kot tudi ne učinkovitih rešitev. Kemično obvladovanje marmorirane smrdljivke vezano na pragove škodljivosti, zahteva veliko število škropljenj, kar negativno vpliva na agroekosistem, obremenjuje okolje in je v popolnem nasprotju z vzpostavljenim sistemom integriranega varstva. Proti škodljivcu imamo trenutno v Sloveniji registrirana zgolj dva kemična pripravka; Karate Zeon 5 CS in Mospilan 20 SG, ki imata kot aktivno snov lambda-cihalotrin in acetamiprid, kar ju uvršča pod širokospektralne insekticide. Uporaba le teh je samo kratkoročna rešitev, saj lahko stenica s časom razvije odpornost. Ne-ciljno delovanje teh sredstev prizadene tudi koristne organizme, kot so naravni sovražniki. Slednjim pripisujemo velik pomen pri obvladovanju marmorirane smrdljivke v Sloveniji. Dolgoročno gre pričakovati, da se bodo domorodni koristi organizmi sčasoma prilagodili na novega tujerodnega škodljivca ter ga začeli omejevati na dopustno raven. Trenutno potekajo raziskave, kjer raziskovalci iz KGZS - KGZ Nova Gorica preučujejo zastopanost jajčnih parazitoidov marmorirane smrdljivke v Sloveniji. Potrdili so zastopanost treh vrst; Anastatus bifasciatus, Trissolcus mitsukurii ter Ooencyrtus telenomicida (Rot in sod., neobjavljeno). Raziskovalna skupina sočasno preučuje tudi učinkovitost parazitiranja omenjenih vrst. Rezultati raziskav domorodnih jajčnih parazitoidov stenic bodo prispevali $\mathrm{k}$ boljšemu poznavanju domorodne koristne favne ter njenega odziva ob vnosu in naselitvi nove tujerodne vrste (marmorirane smrdljivke). Eno izmed alternativnih rešitev bi lahko predstavljalo tudi sajenje privabilnih rastlin, s katerimi odvrnemo pojav škodljivca na glavni rastlini in njegovo zatiranje na privabilni rastlini z uporabo biotičnih agensov (entomopatogene glive, ento- 
mopatogene ogorčice), sesalcev za mehansko odstranjevanje žuželk z rastlin in ožiganja rastlin.

Izkušnje iz tujine kažejo, da je obvladovanje marmorirane smrdljivke izjemno zahteven proces, ki mora združevati številne ukrepe varstva rastlin. Temeljiti morajo na zanesljivih metodah spremljanja populacije škodljivca, predvidevanju nastanka škode ter pravočasni napovedi in izvedbi ukrepov. Poznavanje bionomije marmorirane smrdljivke $\mathrm{v}$ lokalnih razmerah, je predpogoj za načrtovanje ukrepov za prebivalce $\mathrm{v}$ naseljih ter preprečevanje škode $\mathrm{v}$ kmetijski pridelavi.

\section{ZAHVALA}

Prispevek je nastal v sklopu projekta CRP V4-2002, ki je financiran s strani Javne agencije za raziskovalno dejavnost Republike Slovenije (ARRS) in Ministrstva za kmetijstvo, gozdarstvo in prehrano Republike Slovenije (MKGP). V projektu poleg vodilnega partnerja (UL - Biotehniška fakulteta) sodelujejo tudi KGZS - KGZ Nova Gorica in Maribor, UM - Fakulteta za kmetijstvo in biosistemske vede, Inštitut za hmeljarstvo in pivovarstvo Slovenije, Kmetijski inštitut Slovenije in UL - Fakulteta za strojništvo.

\section{REFERENCE}

Abram, P.K., Hoelmer, K.A., Acebes-Doria, A. et al. (2017). Indigenous arthropod natural enemies of the invasive brown marmorated stink bug in North America and Europe. Journal of Pest Science, 90, 1009-1020. https://doi.org/10.1007/ s10340-017-0891-7

Aldrich, J.R., Khrimian, A., Camp, M.J. (2007). Methyl 2,4,6-decatrienoates attract stink bugs and tachinid parasitoids. Journal of Chemical Ecology, 33, 801-815. https://doi. org/10.1007/s10886-007-9270-9

Arakawa, R., Nakamura, Y. (2002). Effects of temperature on development of three Trissolcus spp. (Hymenoptera: Scelionidae), egg parasitoids of the brown marmorated stink bug, Halyomorpha halys (Hemiptera: Pentatomidae). Entomological Science, 5, 215-218.

Bae, S.D., Kim, H.J., Lee, G.H. et al. (2008). Susceptibility of stink bugs collected in soybean fields in Milyang to some insecticides. Korean Journal of Applied Entomology, 47, 413-419.

Bergmann, E.J., Raupp, M.J. (2014). Efficacies of common ready to use insecticides against Halyomorpha halys (Hemiptera: Pentatomidae). Florida Entomolist, 97, 791-800. https:// doi.org/10.1653/024.097.0262

Borges, M., Moraes, M.C.B., Peixoto, M.F. et al. (2011). Monitoring the Neotropical brown stink bug Euschistus heros (F.) (Hemiptera: Pentatomidae) with pheromone-baited traps in soybean fields. Journal of Applied Entomology, 135, 6880. https://doi.org/10.1111/j.1439-0418.2010.01507.x
Burjanadze, M., Gorgadze, O., De Luca, F. et al. (2020). Potential of native entomopathogenic nematodes for the control of brown marmorated stink bug Halyomorpha halys in Georgia. Biocontrol Science and Technology, 30, 962-974. https://doi.org/10.1080/09583157.2020.1776217.

Candian, V., Pansa, M.G., Briano, R. et al. (2018). Exclusion nets: a promising tool to prevent Halyomorpha halys from damaging nectarines and apples in NW Italy. Bulletin of Insectology, 71, 21-30.

Cesari, M., Maistrello, L., Ganzerli, F. et al. (2015). A pest alien invasion in progress: potential pathways of origin of the brown marmorated stink bug Halyomorpha halys populations in Italy. Journal of Pest Science, 88, 1-7. https://doi. org/10.1007/s10340-014-0634-y

Cook, S. M., Smart, L. E., Martin, J. L. et al. (2006). Explotation of host plant preferences in pest management strategies for oilseed rape (Brassica napus). Entomologia Experimentalis et Applicata, 119, 221-229.

Costi, E., Haye, T., Maistrello, L. (2019). Surveying native egg parasitoids and predators of the invasive Halyomorpha halys in Northern Italy. Journal of Pest Science, 143, 299-307. https://doi.org/10.1111/jen.12590

Da San Gallo, P.P. (1679). Esperienze intorno alla generazione delle zanzare fatte da Pietro Paolo da Sangallo fiorentino, e da lui scritte in una lettera allillustrissimo sig. Firenze (Italy): Francesco Redi, Vincenzo Vangelisti Stampatore Arcivescovale, $1-27$.

Dieckhoff, C., Tatman, K.M., Hoelmer, K.A. (2017). Natural biological control of Halyomorpha halys by native egg parasitoids: a multi-year survey in northern Delaware. Journal of Pest Science, 90, 1143-1158. https://doi.org/10.1007/ s10340-017-0868-6

Frank, D.L., Biggs, A.R. (2014). Control of oriental fruit moth and other insect pests in peach, 2013. Arthropod Management Tests, 39, B2. https://doi:10.4182/amt.2014.B2.

Gouli, V., Gouli S., Skinner, M. et al. (2012). Virulence of select entomopathogenic fungi to the brown marmorated stink bug, Halyomorpha halys (Stål) (Hemiptera: Pentatomidae). Pest Management Science, 68, 155-157. https://doi. org/10.1002/ps.2310

Haye, T., Fischer, S., Zhang, J. et al. (2015). Can native egg parasitoids adopt the invasive brown marmorated stink bug, Halyomorpha halys (Heteroptera: Pentatomidae), in Europe? Journal of Pest Science, 88, 693-705. https://doi. org/10.1007/s10340-015-0671-1

Herbert, D.A., Malone, S., Arrington, M. et al. (2013). Evaluation of selected foliar insecticides for control of stink bug in soybean, 2012. Arthropod Management Tests, 38, F64. https://doi.org/10.1093/amt/31.1.F39

Hill, N., Lenglet, A., Arnz, A.M. et al. (2007). Plant based insect repellent and insecticide treated bed nets to protect against malaria in areas of early evening biting vectors: Double blind randomised placebo controlled clinical trial in the Bolivian Amazon. BMJ (Clinical research ed), 335: https://doi. org/10.1136/bmj.39356.574641.55.

Hoebeke, E.R., Carter, E.M. (2003). Halyomorpha halys (Stål) (Heteroptera: Pentatomidae): a polyphagous plant pest from Asia newly detected in North America. Proceedings of Entomological Society Washington, 105, 225-237. 
Inkley, D.B. (2012). Characteristics of home invasion by the brown marmorated stink bug (Hemiptera: Pentatomidae). Journal of Entomological Science, 47, 125-130. https://doi. org/10.18474/0749-8004-47.2.125

Isman, M.B. (2006). The role of botanical insecticides, deterrents and repellents in modern agriculture and an increasingly regulated world. Annual Review of Entomology, 51, 45- 66. https://doi.org/10.1146/annurev.ento.51.110104.151146

Joseph, S.V., Bergh, J.C., Wright, S.E. et al. (2013). Factors affecting captures of brown marmorated stink bug, Halyomorpha halys (Hemiptera: Pentatomidae), in baited pyramid traps. Journal of Entomological Science, 48, 43-51. https://doi. org/10.18474/0749-8004-48.1.43

Kamminga, K.L., Herbert, D.A., Kuhar, T.P. et al. (2009). Predicting black light trap catch and flight activity of Acrosternum hilare (Hemiptera: Pentatomidae) adults. Environmental Entomology, 38, 1716-1723. https://doi. org/10.1603/022.038.0625

Khrimian, A., Shearer, P.W., Zhang, A. et al. (2008). Field trapping of the invasive brown marmorated stink bug, Halyomorpha halys, with geometric isomers of methyl 2,4,6-decatrienoate. Journal of Agricultural Food Chemistry, 56, 197-203. https://doi.org/10.1021/jf072087e

Khrimian, A., Zhang, A., Weber, D.C.et al. (2014). Discovery of the aggregation pheromone of the brown marmorated stink bug (Halyomorpha halys) through the creation of stereoisomeric libraries of 1-bisabolen-3-ols. Journal of Natural Products, 77, 1708-1717. https://doi.org/10.1021/ np5003753

Krawczyk, G., Hull, L.A., Enyeart, T.R. et al. (2011). Brown marmorated stink bug in Pennsylvania fruit orchards: results of BMSB adults direct contact laboratory bioassays and 2011 PA field experience update. Presentation, Brown Marmorated Stink Bug Working Group Meeting, June 20, 2011, Biglerville, PA. http://www.stopbmsb.org/stopBMSB/ assets/File/Research/BMSB-IWG-Jun-2011/BMSB-PAUpdate-Krawczyk.pdf

Krupke, C.H., Brunner, J.F., Doerr, M.D. et al. (2001). Field attraction of the stink bug Euschistus conspersus (Hemiptera: Pentatomidae) to synthetic pheromone-baited host plants. Journal of Economic Entomology, 94, 1500-1505. https:// doi.org/10.1603/0022-0493-94.6.1500

Kuhar, T.P., Doughty, H., Kamminga, K. et al. (2012). Evaluation of foliar insecticides for the control of brown marmorated stink bug in tomatoes in Virginia, 2011. Arthropod Management Tests, 37, E72. https://doi.org/10.4182/amt.2012.E72.

Kuhar, T.P., Short, D.B., Krawczyk, G. et al. (2017). Deltamethrin-incorporated nets as an integrated pest management tool for the invasive Halyomorpha halys (Hemiptera: Pentatomidae). Journal of Economic Entomology, 110, 543-545https://doi.org/10.1093/jee/tow321.

Kuhar, T.P., Kamminga, K. (2017). Review of the chemical control research on Halyomorpha halys in the USA. Journal of Pest Science, 90, 1021-1031. https://doi.org/10.1007/ s10340-017-0859-7

Lee, D.H., Short, B.D., Joseph, S.V. et al. (2013a). Review of the Biology, Ecology, and Management of Halyomorpha halys (Hemiptera: Pentatomidae) in China, Japan, and the Re- public of Korea. Environmental Entomology, 42, 627-641. https://doi.org/10.1603/EN13006

Lee, D.H., Wright, S.E., Leskey, T.C. (2013b). Impact of insecticide residue exposure on the invasive pest, Halyomorpha halys (Hemiptera: Pentatomidae): analysis of adult mobility. Journal of Economic Entomology, 106, 150-158. https:// doi.org/10.1603/EC12265

Lee, D.H., Leskey, T.C. (2015). Flight behavior of foraging and overwintering brown marmorated stink bug, Halyomorpha halys (Hemiptera: Pentatomidae). Entomological Research, 10, 566-573. https://doi.org/10.1017/S0007485315000462

Leskey, T.C., Hamilton, G.C., Nielsen, A.L. et al. (2012a). Pest status of the brown marmorated stink bug, Halyomorpha halys in the USA. Outlook Pest Management, 23, 218-226. https://doi.org/10.1564/23oct07

Leskey, T.C., Hogmire, H.W. (2005). Monitoring stink bugs (Hemiptera : Pentatomidae) in mid-Atlantic apple and peach orchards. Journal of Economic Entomology, 98,143153. https://doi.org/10.1093/jee/98.1.143

Leskey, T.C., Khrimian, A., Weber, D.C. et al. (2015). Behavioral responses of the invasive Halyomorpha halys (Stål) to traps baited with stereoisomeric mixtures of 10,11-epoxy1-bisabolen-3-ol. Journal of Chemical Ecology, 41, 418-429. https://doi.org/10.1007/s10886-015-0566-x

Leskey, T.C., Lee, D.-H., Short, B.D. et al. (2012b). Impact of insecticides on the invasive Halyomorpha halys (Hemiptera: Pentatomidae): analysis of insecticide lethality. Journal of Economic Entomology, 105, 1726-1735. https://doi. org/10.1603/EC12096

Leskey, T.C., Nielsen, A. (2018). Impact of the Invasive Brown Marmorated Stink Bug in North America and Europe: History, Biology, Ecology, and Management. Annual Review of Entomology, 63, 599-608. https://doi.org/10.1146/annurevento-020117-043226

Leskey, T.C., Short, B.D., Butler, B.R. et al. (2012c). Impact of the invasive brown marmorated stink bug, Halyomorpha halys (Stål), in mid-Atlantic tree fruit orchards in the United States: case studies of commercial management. Psyche: A Journal of Entomology, 2012, 1-14. https://doi. org/10.1155/2012/535062

Leskey, T.C., Short, B.D., Lee, D.H. (2014). Efficacy of insecticide residues on adult Halyomorpha halys (Stal) (Hemiptera: Pentatomidae) mortality and injury in apple and peach orchards. Pest Management Science, 70, 1097-1104. https://doi.org/10.1002/ps.3653

Li, Z.X, Liu, Y.S. (2004). Effect of temperature on development of egg parasitoid Trissolcus halyomorphae and the eggs of its host, Halyomorpha halys. Chinese Journal of Biological control, 20, 64-66.

Mathews, C.R., Blaauw, B., Dively, G. et al. (2017). Evaluating a polyculture trap crop for organic management of $\mathrm{Ha}$ lyomorpha halys and native stink bugs in peppers. Journal of Pest Science, 90, 1245-1255. https://doi.org/10.1007/ s10340-017-0838-z.

Mooneyham, K.L., Aigner, J.D., Kuhar, T.P. (2016). Control of brown marmorated stink bug with insecticide-treated window screens. Arthropod Management Tests, 41, tsw021. https://doi.org/10.1093/amt/tsw021

Moore, S.J., Lenglet, A., Hill, N. (2007). Plant-based insect re- 
pellents. In: Insect repellents: principles, methods and uses. Ur. Debboun, S.P. Frances, D. Strickman. CRC Press, New York, NY, 275- 303.

Morrison, W.R., Lee, D.H., Short, B.D. et al. (2016). Establishing the behavioral basis for an attract-and-kill strategy to manage the invasive Halyomorpha halys (Stål) (Hemiptera: Pentatomidae) in apple orchards. Journal of Pest Science, 89, 81-96. https://doi.org/10.1007/s10340-015-0679-6

Morrison, W.R., Milonas, P., Kapantaidaki, D.E. et al. (2017). Attraction of Halyomorpha halys (Hemiptera: Pentatomidae) haplotypes in North America and Europe to baited traps. Scientific Reports, 7, 16941. https://doi.org/10.1038/ s41598-017-17233-0

Nielsen, A.L., Hamilton, G. C., Matadha, D. (2008). Developmental rate estimation and life table analysis for Halyomorpha halys (Hemiptera: Pentatomidae). Environmental Entomology, 37, 348-355. https://doi.org/10.1603/0046-225X(2 008)37[348:DREALT]2.0.CO;2

Nielsen, A.L., Hamilton, G.C. (2009). Seasonal occurence and impact of Halyomorpha halys (Hemiptera: Pentatomidae) in tree fruit. Journal of Economic Entomology, 102, 11331140. https://doi.org/10.1603/029.102.0335

Nielsen, A.L., Hamilton, G.C., Shearer, P.W. (2011). Seasonal phenology and monitoring of the non-native Halyomorpha halys (Hemiptera: Pentatomidae) in Soybean. Environmental Entomology, 40, 231-238. https://doi.org/10.1603/ EN10187

Nielsen, A.L., Holmstrom, K., Hamilton, G.C. et al. (2013). Use of black light traps to monitor the abundance, spread, and flight behavior of Halyomorpha halys (Hemiptera: Pentatomidae). Journal of Economic Entomology, 106, 1495-1502. https://doi.org/10.1603/ec12472

Nielsen, A.L., Rucker, A. (2013). Brown marmorated stink bug control at harvest on peach, 2012. Arthropod Management Tests, 38, B8. https://doi.org/10.4182/amt.2013.B8

Nielsen, A.L., Dively, G., Pote, J.M. et al. (2016). Identifying a potential trap crop for a novel insect pest, Halyomorpha halys (Hemiptera: Pentatomidae), in organic farms. Environmental Entomology, 2016, 1-7. https://doi.org/10.1093/ ee/nvw006

Panizzi, A.R., McPherson, J.E., James, D.G. et al. (2000). Stink bugs (Pentatomidae). V: Schaefer C.W., Panizzi, A.R. (ur.) Heteroptera of economic importance. Boca Raton, CRC, 421-474.

Rice, K.B., Bergh, C.J., Bergmann, E.J. et al. (2014). Biology, ecology and management of brown marmorated stink bug (Halyomorpha halys). Journal of Integrated Pest Management, 5, A1-A13 https://doi.org/10.1603/IPM14002

Rice, K.B, Bedoukian, R.H., Hamilton, G.C. et al. (2018). Enhanced response of Halyomorpha halys (Hemiptera: Pentatomidae) to its aggregation pheromone with ethyl decatrienoate. Journal of Economic Entomology, 111, 495-499. https://doi.org/10.1093/jee/tox316.
Rot, M., Devetak, M., Carlevaris, B. et al. (2018). First record of brown marmorated stink bug (Halyomorpha halys [Stål, 1855]) (Hemiptera: Pentatomidae) in Slovenia. Acta Entomologica Slovenica, 26, 5-12.

Sabbatini Peverieri, G., Binazzi, F., Marianelli, L. et al. (2018). Lethal and sublethal effects of long-lasting insecticide-treated nets on the invasive bug Halyomorpha halys. Journal of Applied Entomology, 142, 141-148. https://doi.org/10.1111/ jen. 12428

Sauphanor, B., Severac, G., Maugin, S. et al. (2012). Exclusion netting may alter reproduction of the codling moth (Cydia pomonella) and prevent associated fruit damage to apple orchards. Entomologia Experimentalis et Applicata, 145, 134142. https://doi.org/10.1111/j.1570-7458.2012.01320.x

Soergel, D.C., Ostiguy, N., Fleischer S.J. et al. (2015): Sunflower as potential trap crop of Halyomorpha halys (Hemiptera: Pentatomidae) in pepper fields. Environmental Entomology, 44, 1581-1589. https://doi.org/10.1093/ee/nvv136.

Trdan, S., Valič, N., Žnidarčič, D. et al. (2005). The role of Chinese Cabbage as a trap crop for flea beetles (Coleoptera: Chrysomelidae) in production of white cabbage. Scientia Horticulturae, 106, 12-24.

Walgenbach, J.F., Schoof, S.C. (2015). Peach insecticide trial, 2013. Arthropod Management Tests, 39, B10. https://doi. org/10.4182/amt.2014.B10

Weber, D.C., Leskey, T.C., Cabrera Walsh, G. et al. (2014). Synergy of aggregation pheromone with methyl (E, E, Z)-2,4,6decatrienoate in attraction of Halyomorpha halys (Hemiptera: Pentatomidae). Journal of Economic Entomology, 107, 1061-1068. https://doi.org/10.1603/ec13502.

Yang, Z.Q., Yao, Y. X., Qiu, L.F. et al. (2009). A new species of Trissolcus (Hymenoptera: Scelionidae) parasitizing eggs of Halyomorpha halys (Heteroptera: Pentatomidae) in China with comments on its biology. Annals of the Entomological Society of America, 102, 39-47. https://doi. org/10.1603/008.102.0104

Zhang, Q.-H., Schneidmiller, R.G., Hoover, D.R. (2013). Essential oils and their compositions as spatial repellents for pestiferous social wasps. Pest Management Science, 69, 542- 552. https://doi.org/ 10.1002/ps.3411

Zhang, Q.-H., Schneidmiller, R.G., Hoover, D.R. et al. (2014). Essential oils spatial repellents fort he brown marmorated stink bug, Halyomorpha halys (Stål) (Hemiptera: Pentatomidae). Journal of Applied Entomology, 138, 490-499. https://doi.org/10.1111/jen.12101

Zobel, E.S., Dively, G.P., Hooks, C.R.R. (2016). Seasonal abundance, host suitability, and feeding injury of the brown marmorated stink bug, Halyomorpha halys (Heteroptera: Penatomidae), in selected vegetables. Journal of Economic Entomology, 109, 1289-1302. https://doi.org/10.1093/jee/ tow055 